\title{
Combining sense of place theory with the ecosystem services concept: empirical insights and reflections from a participatory mapping study
}

\author{
Sarah Gottwald (D) Christian Albert $\mathbb{D} \cdot$ Nora Fagerholm $(\mathbb{D}$
}

Received: 8 October 2020/ Accepted: 19 October 2021 / Published online: 26 October 2021

(C) The Author(s) 2021

\begin{abstract}
Context River landscapes represent hotspots for biodiversity and ecosystem services used and embraced by human agents. Changes in river landscapes are subjectively perceived by people and can be assessed through the lenses of cultural ecosystem services (CES) and sense of place (SOP).

Objectives This study aims to assess people-place relationships in a river landscape by integrating SOP theory and the CES concept and critically reflecting on their interplay. Research objectives relate to meanings and attachments attributed by citizens to places and the influence of the physical environment and socioeconomic settings.
\end{abstract}

Supplementary Information The online version contains supplementary material available at https://doi.org/10.1007/ s10980-021-01362-z.

S. Gottwald $(\bowtie) \cdot$ C. Albert

Ruhr University Bochum, Institute of Geography, Chair for Environmental Analysis and Planning in Metropolitan Regions, Universitaetsstr. 150, 44801 Bochum, Germany e-mail: Sarah.Gottwald@ruhr-uni-bochum.de

S. Gottwald

Leibniz University Hannover, Institute of Environmental Planning, Herrenhaeuser Str. 2, 30419 Hannover,

Germany

N. Fagerholm

Department of Geography and Geology, University of

Turku, Turku, Finland
Methods We employed a spatially meaningful place indicator in a public participation GIS survey, combining meanings elucidated through a free listing exercise and multiple-choice questions. Statistical analyses were employed to investigate relationships between meanings, place attachment, and environmental and social variables.

Results The results showed that (1) place meaning assessments can complement place attachment data by enhancing the understanding of relationships to biophysical and socioeconomic variables, and (2) combinations of both assessment approaches for place meanings showed that CESs were reflected in many free listed meaning types, dominantly related to forms or practices, but neglect relational values, such as "Heimat" (i.e., in German expression of the longstanding connection to an area) or memories.

Conclusions This paper explicates synergies between SOP theory and CES concept. CES research offers insights from spatial assessments, while SOP research provides theoretical depth regarding relational values linked to CES. This paper critically reflects the ostensible consent of understanding SOP as a CES and proposes considering SOP as an overarching theory for CES assessment.

Keywords River landscape - Relational values · Cultural ecosystem services · Place attachment - Place meanings $\cdot$ Participatory mapping $\cdot$ PPGIS 


\section{Introduction}

The spatially explicit assessment of social values has proven beneficial for planning and management. The integration of spatial, social, and perceptual data into land use planning enhances the understanding of reasons and impacts of change (Ryan 2011), minimizes potential land use conflicts and enhances environmental stewardship (Ives et al. 2015). River landscapes, which are complex social-ecological systems, represent a hotspot for biodiversity (Dudgeon et al. 2006) and for certain cultural ecosystem services, such as aesthetic quality (Thiele et al. 2019). Moreover, river landscapes demonstrate close linkages between cultural use and biophysical dynamics, which can be seen, for example, when adapting management to the hydrological regime of the river (Wantzen et al. 2016). However, many rivers worldwide are in peril, impacting both biodiversity and human lives (Vörösmarty et al. 2010). It is critical to understand that social ecological systems, such as river landscapes, and their changes are subjectively perceived by people (Stedman 2016). However, there is a lack of understanding on how people feel emotionally toward these rivers and their landscapes. Previous studies focus on specific recreational activities highlighting the importance of the river setting, e.g., proximity to the river, for emotional connections or specifically place dependence (Kainzinger et al. 2018). A comparative study by Verbrugge et al. (2019) presents five cases that use different approaches to assess SOP for integration in participatory processes, highlighting the need to engage with people-place relationships in river landscapes.

Sense of place (SOP) has been suggested as a very promising approach to understanding people-place relationships (Stedman 2016). In this article, we employ the definition by Tuan (1977), who describes SOP as the meanings and attachments that people or groups attribute to place. Stedman (2016) further highlights the evaluative character of place attachment and the descriptive character of place meanings. Place attachments are defined as emotional connections to a place and can be further divided into the intensity and dimensions of attachment, such as place identity and dependence (Lewicka 2011). Place identity is an emotional dimension of attachment, measured with items such as "I feel X is a part of me". Place dependence focuses on the functional attachment assessed for example with items such as " $\mathrm{X}$ is the best place for what I like to do". Place dependence may have some descriptive characteristics, but the intensity is usually quantitatively evaluated on a 5-point Likert scale (Williams and Vaske 2003; Lewicka 2011). In complementation, place meanings describe in more detail the reasons for this connection (Stedman 2016). These can be simple adjectives (e.g., aesthetic beauty), symbolic interpretations (e.g., spiritual values), or descriptions of the place character (e.g., variety of plants and animals) (Masterson et al. 2017). Place meanings are usually assessed using qualitative methods (Lewicka 2011), such as interviews (Manzo 2005; Knaps and Herrmann 2018) or photoelicitation (Tonge et al. 2013). There are some exceptions to quantitative studies, such as Stedman (2003), who used a Likert scale to evaluate statements such as "My lake is a place to escape from civilisation". In general, SOP research focuses much more on place attachment than on place meaning (Stedman 2008; Lewicka 2011). However, there is no meaning without attachment and no attachment without meaning. The same place can provide different meanings and equally strong attachments for different individuals or equally the same meaning but differently strong attachments (Stedman 2003).

However, spatially assessing SOP or related concepts, such as place attachment, identity, or meaning on its own, has proven challenging. Common methods assessing SOP, such as a proxy measurement (e.g., length of residence), attachment scales or quantitative rankings, neglect cultural associations and biophysical characteristics (Lin and Lockwood 2013). Existing studies on SOP tend to rely on predefined spatial areas, such as administrative boundaries of neighborhoods, national parks, or cities, disregarding the individual interpretation of spatial geometry of places. Administrative units may only poorly represent the actual environmental exposure of an individual (Perchoux et al. 2013; Hasanzadeh et al. 2018). While SOP and place attachment research has been dominated by a focus on social components (Stedman 2003; Lewicka 2011), the physical environment is receiving increased attention (e.g., Brown and Raymond 2007; Gottwald and Stedman 2020). However, the physical environment provides meanings for attachment, e.g., people may feel attached to the beautiful nature or possibilities for recreation of a certain place (Lewicka 2011). In one of the few examples of spatial assessment of 
SOP, Brown and Raymond (2007) asked respondents to allocate areas of place attachment, not including dimensions, intensities, and meanings. They demonstrated that mapped values (special places) are a reasonable proxy for place attachment. Therefore, Brown et al. (2020) argue that the mapping of "place values is an operational means to assess both explicit and implicit place relationship" (p. 3). However, "special places" or "place values" still lack the nuances of SOP theory, specifically the dimensions, intensities of the human nature connection, and specific meanings related to them.

Other related concepts could offer an opportunity for the spatial assessment of SOP. The concepts of ecosystem services (MEA 2005), nature's contribution to people (Díaz et al. 2018), or landscape values, which "describe the sociocultural perception of landscape functions" (Garcia-Martin et al. 2017, p. 2134), have been assessed using participatory and spatial methods in a vast number of studies (for an overview see Brown and Fagerholm 2015). This experience provides researchers with access to established lists of ecosystem services based on, for example, the MEA report (2005) and adapted to regional context (e.g., for Germany Plieninger et al. 2013; Rall et al. 2017). Specifically, cultural ecosystem services (CESs), such as aesthetic values, social relations, or inspiration, provide insight into the immaterial benefits of ecosystems to people (Plieninger et al. 2013). CESs are defined as "ecosystems' contributions to the nonmaterial benefits (e.g., capabilities and experiences) that arise from human-ecosystem relationships" (Chan et al. 2012, p. 9). In particular, a relational value approach to understanding the values (cultural) delivered by ecosystem services provides potential for understanding human-nature relationships. Relational values are gaining increasing attention (see, for example, the recent special issue in environmental sustainability by Chan et al. (2018)), as they are well suited to capture human-nature relationships (Chan et al. 2018) and allow us to account for values that are not necessarily environmental (Klain et al. 2017). This affordance is reflected in the definition of relational value as 'the importance attributed to meaningful relations and responsibilities between humans and between humans and nature' (Arias-Arévalo et al. 2017 , p. 2). This definition is reflected in the understanding of SOP, where place can be characterized by natural elements and the connection to that place, including meanings and attachment, and can be shaped by social or cultural processes (such as social gatherings or traditional festivities), which reflect individual and social experiences (Masterson et al. 2017). This characterization of place is especially true considering a progressive perspective of SOP, which accounts for various dynamic lifestyles, assuming mobility as the natural human condition (Massey 1991; Di Masso et al. 2019). However, there are very few examples that have connected SOP and CES, an exception being Cundill et al. (2017), who used the concept of place attachment to assess relational values of protected areas. In response to this gap in connecting the two approaches, we integrate SOP and CES to spatially assess people-place relationships.

The creation of SOP and perception of ecosystem services is influenced by personal attributes, social relations, sociocultural setting, and the place's attributes (Martín-López et al. 2012; Williams 2014; Masterson et al. 2017; Raymond et al. 2017). Thus, the perception of a meaningful place and the assignment of certain meanings to that place is influenced by the socioeconomic system, including held values (Brown et al. 2020) and personal attributes (Raymond et al. 2017), such as sociodemographic characteristics, environmental attitudes, and local knowledge. Personal attributes, such as sociodemographic characteristics, may have an influence on the perception of the ecosystem. More specifically, higher educated people and women in general are more likely to perceive an ecosystem's capacity to provide services (MartínLópez et al. 2012), which SOP is a part of. However, other studies show only a few and weakly significant relations between sociodemographic characteristics and mapped ecosystem services (Fagerholm et al. 2019). Environmental attitudes (Martín-López et al. 2012) and environmental motivations may influence the perception of ESs and value provision (AriasArévalo et al. 2017). People with stronger environmental attitudes are more likely to perceive ecosystem services, and people with altruistic motivations more often express relational values than people with egoistic motivation (Arias-Arévalo et al. 2017). Furthermore, knowledge about local sociocultural and natural values forms place attachment (Lin and Lockwood 2014).

The physical environment defines the limits of possible constructed and attributed meanings (e.g., fish-related meanings can only be associated with 
places/landscapes where fish can exist) and prefers some meanings of others (e.g., rough rafting rivers may create different types of meanings than wide and calm river surfaces) (Ingalls et al. 2016; Masterson et al. 2017). Stedman (2003) shows that place characteristics have little effect on place attachment but affect place meanings, which in turn are significantly related to attachment. Some studies that employed different designs and definitions of people-place relations argue that natural features, perceived green space, and wildness enhance the sense of community and community attachment (Kim and Kaplan 2004; Arnberger and Eder 2012; Colley and Craig 2019). In contrast, other studies negate such relationships and show that there is no significant association between SOP and neighborhood greenness (McCunn and Gifford 2014). Apart from physical characteristics, the accessibility of a place is a determinant for the experienced SOP. Within this study, this accessibility is operationalized by the distance to the home location and the shortest distance to the river. Studies have shown that place attachment to the apartment or house and city scale is higher than that to the neighborhood (Hidalgo and Hernandez 2001; Lewicka 2010).

The aim of this study is to assess people-place relationships in a river landscape by integrating SOP theory and the CES concept and critically reflecting on the relation and interplay between these two approaches. Specifically, SOP is spatially assessed at the Lahn River landscape in Germany. This research is guided by the following questions:

(1) Which meanings and attachments have been attributed to meaningful places located by respondents?

(2) How do physical environment and socioeconomic variables influence meanings and attachments of meaningful places?

\section{Method}

Case study: Lahn river landscape

The study took place at the Lahn River and its surrounding area, located in central western Germany (Fig. 1). The river is a $246 \mathrm{~km}$ long tributary of the Rhine River. It crosses three federal states and has a watershed of approximately $6000 \mathrm{~km}^{2}$. Our study focuses on the river stretch in the federal state of Hesse $(140 \mathrm{~km})$, including a $5 \mathrm{~km}$ wide buffer on each side of the river. There are several medium- and smallsized settlements creating a rural-peri urban-urban mix. The river margins are dominated by grassland, agricultural fields, and some forests. A highway is located next to the river. The river is mainly used for tourist and recreational activities such as boating (motor and nonmotorized), fishing, and hiking. Flood regulation requirements, settlement, and agricultural development, as well as previous demands for the transportation of goods, led to the construction of approximately 70 sluices and weirs. These require costly maintenance, and their current need is debated (Albert et al. 2019). The ecological status of the river and its valley is considered medium to poor, according to water framework directive assessments (HMUKLV 2015).

Survey design and data collection

To gain insight into the spatial SOP, place attachment and place meanings were assessed with a PPGIS survey. We used the online PPGIS platform Maptionnaire ${ }^{\mathrm{TM}}$ for survey creation. Participants were asked to locate up to three meaningful places on a map and provide further details in survey questions relating to each located point. We applied a common approach to measure place attachment using a 5-point Likert scale with nine statements, drawing on spatial and mostly nonspatial scales of place attachment representing the dependence and identity dimensions (Williams and Vaske 2003; Stedman 2006; Raymond et al. 2010). To assess place meanings, we employed a list of CESs that had been established for spatial assessment purposes in Germany and used in two different cases (Plieninger et al. 2013; Rall et al. 2017). Respondents could choose as many of the following nine CESs: aesthetic appreciation, cultural heritage, local history and culture, nature experience and education, spiritual services, inspiration, biodiversity, natural significance, social relations, and recreation (see Table 1 for the wording used in the survey). However, predefined lists may not capture the entire breadth of meanings, which can be very diverse and individual. Therefore, the survey included the open question 'Why is this place meaningful to you?', allowing a free-listing activity (Wartmann and Purves 2018). 


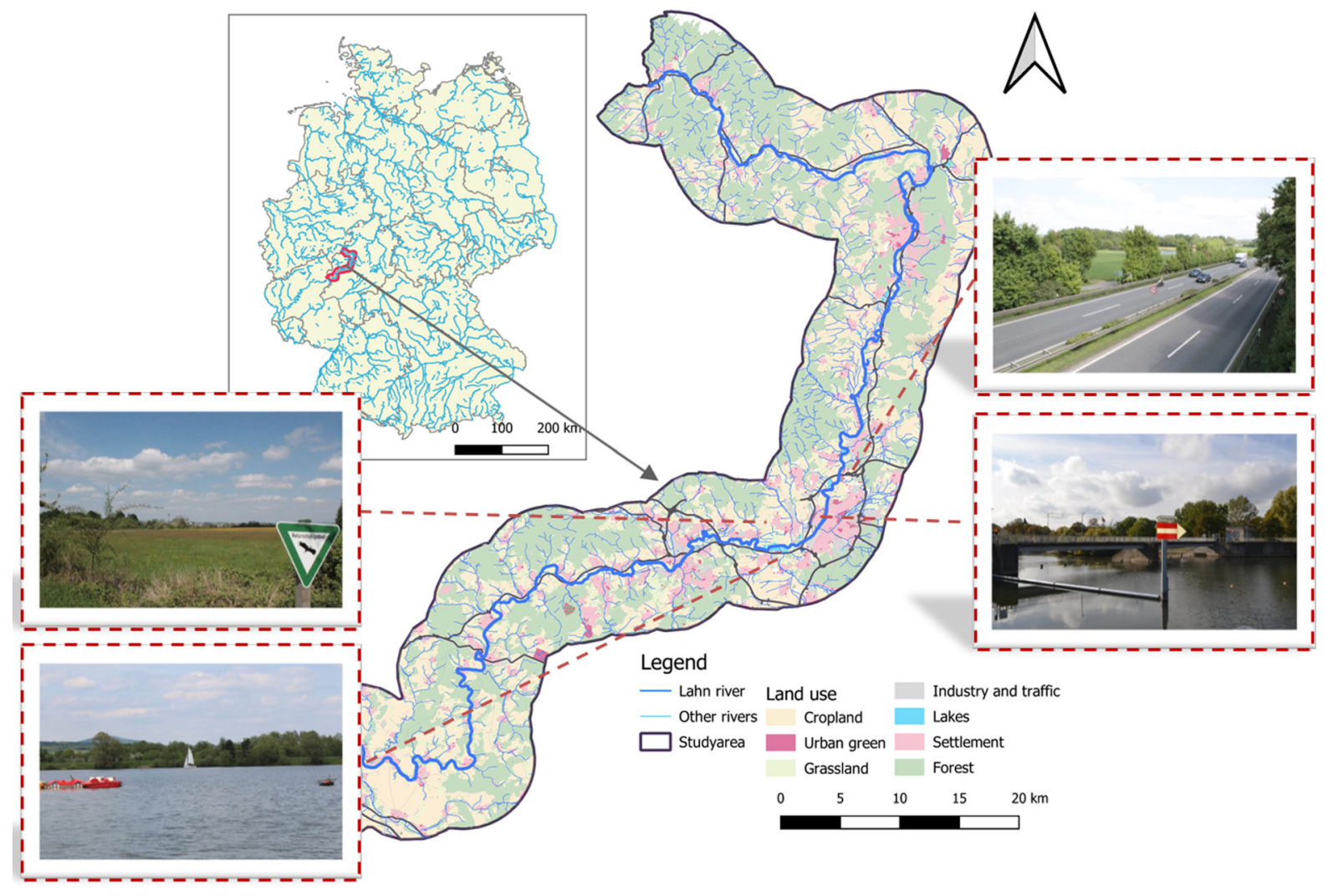

Fig. 1 Study area with illustrative photographs (taken by author)

Additionally, personal attributes were assessed in the survey, which are psychological and sociodemographic attributes. The first reflects the respondents' attitudes toward the environment ('environmental citizenship') and their local knowledge. We used the environmental citizenship factor of the Pro Environmental Behavior scale by (Markle 2013) and focused on those four items that are relevant for this study. The excluded items on car use and organic vegetable consumption were seen as too specific and out of scope for this study. The remaining items are 'Are you currently a member of any environmental, conservation, or wildlife protection group?', 'During the past year have you contributed money to an environmental, conservation, or wildlife protection group?' (coded yes/no), 'How frequently do you watch television programs, movies, or internet videos about environmental issues?', and 'How often do you talk to others about their environmental behavior?' (both: "never" (1), “ rarely" (2), “ sometimes" (3), “ often” (4), “ constantly" (5)). The scale included two other items: "I want to live as ecologically as possible" and "I am very concerned about environmental issues". The latter two were recoded into a 5-point Likert scale and added to the whole scale as they increased Cronbach's alpha from 0.55 to 0.64 . The variable environmental citizenship thus represents the mean value of all 6 items and ranges between 1 and $5(\min =1$, $\max =$ 4.8, $\mathrm{M}=3.2, \mathrm{SD}=0.76$ ). Local knowledge was measured using four subvariables: knowledge on general, environmental, social, and economic local topics $(1=$ no knowledge and $5=$ very sound knowledge). The final variable 'local knowledge' represents the mean value of all four types of local knowledge. Sociodemographic variables consist of age (continuous), gender (binary), education (scale), and income (scale).

Finally, the physical environment was described using the variables land use types, protection status (proportion of protected area within $500 \mathrm{~m}$ radius), 
Table 1 Assessed variables

\begin{tabular}{|c|c|c|c|c|}
\hline Variable & & Measured items & Reference & Source \\
\hline \multirow[t]{10}{*}{$\begin{array}{l}\text { Sense of place } \\
\text { meaningful } \\
\text { place } \\
\text { indicator }\end{array}$} & $\begin{array}{l}\text { Place } \\
\text { attachment }\end{array}$ & $\begin{array}{l}\text { Place identity } \\
\text { - I am very attached to this place } \\
\text { - This place means a lot to me } \\
\text { - I identify strongly with this place } \\
\text { - I feel this place is part of me } \\
\text { Place dependence } \\
\text { - No other place can compare to this one } \\
\text { - I wouldn't substitute any other place for } \\
\text { doing the types of things I do here } \\
\text { - This place is the best for what I like to } \\
\text { do } \\
\text { - I get more satisfaction out of being here } \\
\text { than at any other place } \\
\text { Additional item } \\
\text { - I feel happiest when I'm at this place }\end{array}$ & $\begin{array}{l}\text { (Williams and } \\
\text { Vaske 2003; } \\
\text { Stedman 2006; } \\
\text { Raymond et al. } \\
\text { 2010) }\end{array}$ & PPGIS survey, spatial \\
\hline & \multirow[t]{8}{*}{$\begin{array}{l}\text { Place meaning } \\
\text { 1: Cultural } \\
\text { ecosystem } \\
\text { services (CES) }\end{array}$} & $\begin{array}{l}\text { Aesthetic appreciation: "Scenery, sights, } \\
\text { particular beauty" } \\
\text { Cultural heritage: "Local history and } \\
\text { culture" }\end{array}$ & \multirow[t]{8}{*}{$\begin{array}{l}\text { (MEA 2005; } \\
\text { Plieninger et al. } \\
\text { 2013; Rall et al. } \\
\text { 2017) }\end{array}$} & \multirow[t]{8}{*}{ PPGIS survey, spatial } \\
\hline & & $\begin{array}{l}\text { Nature experience and education: } \\
\text { "Opportunity to learn about, observe } \\
\text { and experience nature" }\end{array}$ & & \\
\hline & & $\begin{array}{l}\text { Spiritual services: "Sacred, religious, or } \\
\text { spiritual aspects" }\end{array}$ & & \\
\hline & & $\begin{array}{l}\text { Inspiration: "Inspirational aspects of } \\
\text { nature, where one might be stimulated } \\
\text { with new thoughts, ideas or creative } \\
\text { impulses" }\end{array}$ & & \\
\hline & & $\begin{array}{l}\text { Biodiversity: "Variety of plants and } \\
\text { animals" }\end{array}$ & & \\
\hline & & $\begin{array}{l}\text { Natural significance: "Significance for } \\
\text { native animals, plants, ecosystems or } \\
\text { geological features" }\end{array}$ & & \\
\hline & & $\begin{array}{l}\text { Social relations: "Opportunity to meet } \\
\text { friends and family" }\end{array}$ & & \\
\hline & & $\begin{array}{l}\text { Recreation: "Opportunities for outdoor } \\
\text { recreation uses" }\end{array}$ & & \\
\hline & \multirow[t]{2}{*}{ Place meaning 2} & $\begin{array}{l}\text { Free listing: „Why is this place } \\
\text { meaningful to you?” }\end{array}$ & & PPGIS survey, spatial \\
\hline $\begin{array}{l}\text { Physical } \\
\text { environment }\end{array}$ & & $\begin{array}{l}\text { Land use types } \\
\text { Protection status (proportion of protected } \\
\text { area within } 500 \text { m radius) } \\
\text { Green space (proportion of green space } \\
\text { within } 500 \mathrm{~m} \text { radius) } \\
\text { Distance from home } \\
\text { Distance from the river }\end{array}$ & (BKG 2016) & $\begin{array}{l}\text { Digital Basic Landscape } \\
\text { Model (2016) provided by } \\
\text { Federal Agency for } \\
\text { Cartography and Geodesy } \\
\text { PPGIS survey (home } \\
\text { location), spatial }\end{array}$ \\
\hline
\end{tabular}


Table 1 continued

\begin{tabular}{|c|c|c|c|c|}
\hline Variable & & Measured items & Reference & Source \\
\hline \multirow[t]{2}{*}{$\begin{array}{l}\text { Psychological } \\
\text { attributes }\end{array}$} & $\begin{array}{l}\text { Environmental } \\
\text { citizenship }\end{array}$ & $\begin{array}{l}\text { Are you currently a member of any } \\
\text { environmental, conservation, or } \\
\text { wildlife protection group?; During the } \\
\text { past year have you contributed money } \\
\text { to an environmental, conservation, or } \\
\text { wildlife protection group? } \\
\text { "Yes" (5), "No" (1) } \\
\text { How frequently do you watch television } \\
\text { programs, movies, or internet videos } \\
\text { about environmental issues?; How often } \\
\text { do you talk to others about their } \\
\text { environmental behaviour? } \\
\text { " Never" (1), " rarely" (2), " } \\
\text { sometimes" (3), " often" (4), " } \\
\text { constantly" (5) } \\
\text { I want to live as ecologically as possible; } \\
\text { I am very concerned about } \\
\text { environmental issues } \\
\text { (5 point Likert scale) } \\
\text { The variable environmental citizenship } \\
\text { thus represents the mean value of all } 6 \\
\text { items and ranges between } 1 \text { and } 5\end{array}$ & (Markle 2013) & PPGIS survey \\
\hline & $\begin{array}{l}\text { Local } \\
\text { knowledge }\end{array}$ & $\begin{array}{l}\text { How do you evaluate your personal } \\
\text { knowledge on LOCAL topics such as: } \\
\text { Social topics (e.g. need for social } \\
\text { housing); Environmental topics (e.g. } \\
\text { high biodiversity areas, pollution risks) } \\
\text { Economic topics (e.g. employment } \\
\text { situation); In General } \\
\text { (No knowledge, Very little knowledge, } \\
\text { Some knowledge, Sound knowledge } \\
\text { (sufficient to act), Very sound } \\
\text { knowledge (could give a detailed } \\
\text { explanation), Not applicable) }\end{array}$ & & PPGIS survey \\
\hline $\begin{array}{l}\text { Socio- } \\
\text { demographic }\end{array}$ & $\begin{array}{l}\text { Age } \\
\text { Gender } \\
\text { Education } \\
\text { Income }\end{array}$ & $\begin{array}{l}\text { Male, Female, Other } \\
\text { Comprehensive school, Secondary } \\
\text { school, Upper secondary school, } \\
\text { Vocational school, Bachelor's degree, } \\
\text { Master's degree, Doctoral degree, Other } \\
\text { Under } 500,500 \text { to under } 900,900 \text { to } \\
\text { under } 1300,1300 \text { to under } 1500,1500 \\
\text { to under } 2000,2000 \text { to under } 2600, \\
2600 \text { to under } 3200,3200 \text { to under } \\
4500,4500 \text { or more }\end{array}$ & & PPGIS survey \\
\hline
\end{tabular}

green space (proportion of green space within $500 \mathrm{~m}$ radius) and distance from the river, which are all based on the digital basic landscape model produced by the German Federal Agency for Cartography and Geodesy (BKG 2016).
A randomized sample of 3000 citizens aged 18 years or older in thirteen communes adjacent to the river received an invitation by mail consisting of a personal letter with an individual code and a guide sheet to complete the survey. After 2 weeks, those who 
did not respond received a reminder post card. The addresses of the participants were obtained from the German Post Agency, a private company storing, analyzing, and selling addresses. Their addresses are based on the local registration offices. Respondents were provided with a video tutorial and an informational page (through external links) explaining how to locate a point on the map. These were accessible directly from the survey. (Link: https://app. maptionnaire.com/en/800/, Fig. S.1 in Supplementary Materials).

Data analysis

For the statistical analysis, we used IBMS SPSS Statistics 26; for GIS visualizations and analyses, we worked with Quantum GIS 3.4.10.
Place meanings are analyzed in three steps (Fig. 2). First, we analyzed the free listed meanings deductively coding them based on Stephenson's (2008) value model. However, some additional codes have been added that are related to the distinct context of a German river landscape. For example, we divided natural features into biotic features (land) and rivers, added social relations, and accessibility. Instead of traditional activities, our code "everyday life" is supposed to include more mundane activities. "Heimat" was used in this specific German context related to Stephenson's value of feeling of belonging. While "Heimat" is an intuitively understood term for German citizens (which have been the target group of this study), there is no straightforward translation to the English language. It may even show similarities to the understandings of SOP. However, "Heimat" is a

\section{Assessing place meanings and attachments}

\section{Place meanings}

1. Free listed meanings coding and frequencies

2. CES frequency and distribution; CES co-occurence (Spearman's rank correlation)

3. Relation between free listed meanings and CES (Spearman's rank correlation)

$\rightarrow$ Creation of final list of place meanings

\section{Place attachment}

1. Factor and reliability analysis

$\rightarrow$ Attaining mean place attachment variable

\section{Analysing the relation to physical environment and socio-economic variables}

\section{Physical environment}

1. GIS visualisation

2. Relation land use and meanings type (Chi-square, standardized residuals)

3. Relation land use place attachment (ANOVA)

4. Relation between distance to home, river, share of protected land use and Sense of Place (Spearman's rank correlation)

\section{Social setting}

1. Relation between local knowledge, environmental citizenship and socio demographic variables

2. Relation between local knowledge, environment citizenship and Sense of place (Spearman's rank correlation)

Fig. 2 Workflow of the analysis procedure to answer the research questions 
very static concept, describing an "long-standing connection to an area, the relevance of (early) socialization experiences, and the feeling of safety and deep familiarity that comes from having settled in a place and being at home there in the full sense of the word" (Ratter and Gee 2012, p. 129). Furthermore, we decided to use "settlement" instead of human-made structures because the study area at stake is generally highly impacted by human activities. Second, we analyzed the allocated CES both statistically (frequencies) and visually using GIS. To gain insights into the cooccurrence of different CESs at meaningful places, Spearman's correlation analyses were used. Third, we conducted a Spearman's rank correlation analysis to elucidate potential reflections of CES within the free listed meanings. These findings led to the compilation of a list of 13 meanings that combines meanings assessed through the free listed and multiple choice (CES) exercise. We joined items that were significantly and positively correlated ( $\mathrm{p}$ value $<$ 0.05 ) and had a similar meaning. For example, 'aesthetic appreciation' (free listing) was joined to 'aesthetic appreciation' (CES list) but not to social relations (CES list) because while the items correlated, their meaning differed substantially. The CES list consists of four items that are very closely linked to experiencing nature ('Learn about nature', 'Inspiration', 'Plants and animals' and 'Native'). They have been joined to biotic features (free listing) forming the variable 'nature' because they have shown significant positive correlations among each other and a high reliability (Cronbach's alpha $=0.712$ ). This list was used in further analysis to assess relationships with place attachment, physical environment, and socioeconomic variables (sociodemographic and psychological attributes).

Place attachment, the evaluative dimension of SOP, was analyzed using factor and reliability analysis (Cronbach's alpha). The differences between the single items were relatively small, and the scale had a high level of internal consistency, as determined by a Cronbach's alpha of $0.915(\mathrm{M}=3.6, \mathrm{SD}=0.74$, listwise exclusion $\mathrm{N}=376$ ). Therefore, a combined variable of all attachment items was created for further analysis, representing the mean value. The mean place attachment value was used to reveal differences between different types of meanings.

The relation to the physical environment was first studied through GIS, visualizing the meaningful places against different land use types. We assessed the distribution of different land use types and compared the distribution of meaningful places within these land use types. Second, for a more detailed understanding of the difference between the types of meanings, the frequency of meanings for each land use type was summed, revealing popular landscapes. To account for relative differences, a residual analysis was used (Brown and Brabyn 2012). Using chi-square analysis and standardized residual values, the frequency of a meaning type in each land use type is set in relation to the total amount of meanings within this land use and the total amount of that meaning type. Significant differences are highlighted in red and green. Third, mean place attachment was compared between the different land use types using one-way ANOVA. Finally, we examined the distance to home and to the river, which were calculated using the QGIS tool connected with lines. We calculated the distance from home based on the home location marked by the respondents of the PPGIS survey. Furthermore, the share of protected area within a $500 \mathrm{~m}$ distance from a meaningful place was calculated. While buffer sizes vary in comparable studies of individual boundaries, the threshold is usually oriented on an easily walkable distance (Kyttä et al. 2015; Hasanzadeh et al. 2017). Spearman's correlations were calculated.

Relationships to socioeconomic variables were analyzed using descriptive statistics and Spearman's rank correlation between environmental citizenship, local knowledge, and sociodemographic background variables. Furthermore, correlation analysis was used to assess the relationship between place meanings and attachment.

\section{Results}

Meaningful place indicator

The survey achieved a response rate of $9.2 \%$ after eliminating invalid responses, such as empty surveys and incorrect codes. A total of 275 respondents located 1689 points of different categories (e.g., meaningful places, activities), of which 243 respondents located 561 meaningful places. Respondents located on average 2.3 meaningful places $(\min =1$, $\max =9$, median =2), $39 \%$ located one place, $19 \%$ located two places, and $29 \%$ located three places. On average, 
Table 2 Comparison of socio-demographic variables between sample and census data, census data based on Hessian State agency for statistics, Wiesbaden, 2019 and 2020, NA = no answer

\begin{tabular}{llc}
\hline Socio-demographic variables & Sample $(\mathrm{N}=275)$ & Census \\
\hline Average age (years) & 46.5 & 45.4 \\
Gender (\%) & & \\
Female & 31.8 & 50.6 \\
Male & 67.4 & 49.4 \\
NA & 0.8 & \\
Income (\%) & & \\
Under 3200 & 52.1 & 83.4 \\
3200 and more & 38.1 & 16.6 \\
NA & 9.7 & \\
\hline
\end{tabular}

respondents were older and male-dominated compared to the regional census (Table 2).

Meaningful places are spatially concentrated all along the river. Most places can be found within municipalities where respondents live. Meaningful places cluster in urban centers and special rural areas, such as river meanders and lakes (Fig. 3).
Descriptive dimension of sense of place: place meanings

The most commonly stated meanings assessed through the free listing exercise were related to recreational activities (33\%), aesthetic values (25.6\%), and wellbeing (21.4\%) (Fig. 4a). In comparison, the most frequently listed meanings through the selection of CES were recreation (65.6\%), aesthetic appreciation (64.9\%), social relations (53\%), and nature experience and education $(52.1 \%$ ) (Fig. 4b). Respondents associated between zero and nine (out of nine) CESs for each meaningful place $(\mathrm{M}=2.72$, median $=3)$. For $26.6 \%$ of the places, there was no CES associated; for most places $(51.2 \%)$, respondents associated between two (14.4\%) and five (10.9\%) CESs per place. For the 412 meaningful places with an associated CES, all were mentioned for at least $25 \%$ of the points, except spiritual services $(5.6 \%)$. A correlation provided evidence that CESs related to nature were most strongly correlated, such as biodiversity and inspiration (rho $=0.351, \mathrm{p}<0.01$ ), recreation showed a significant positive relation to both social relations (rho $=0.174, \mathrm{p}<0.01)$ and education and inspiration

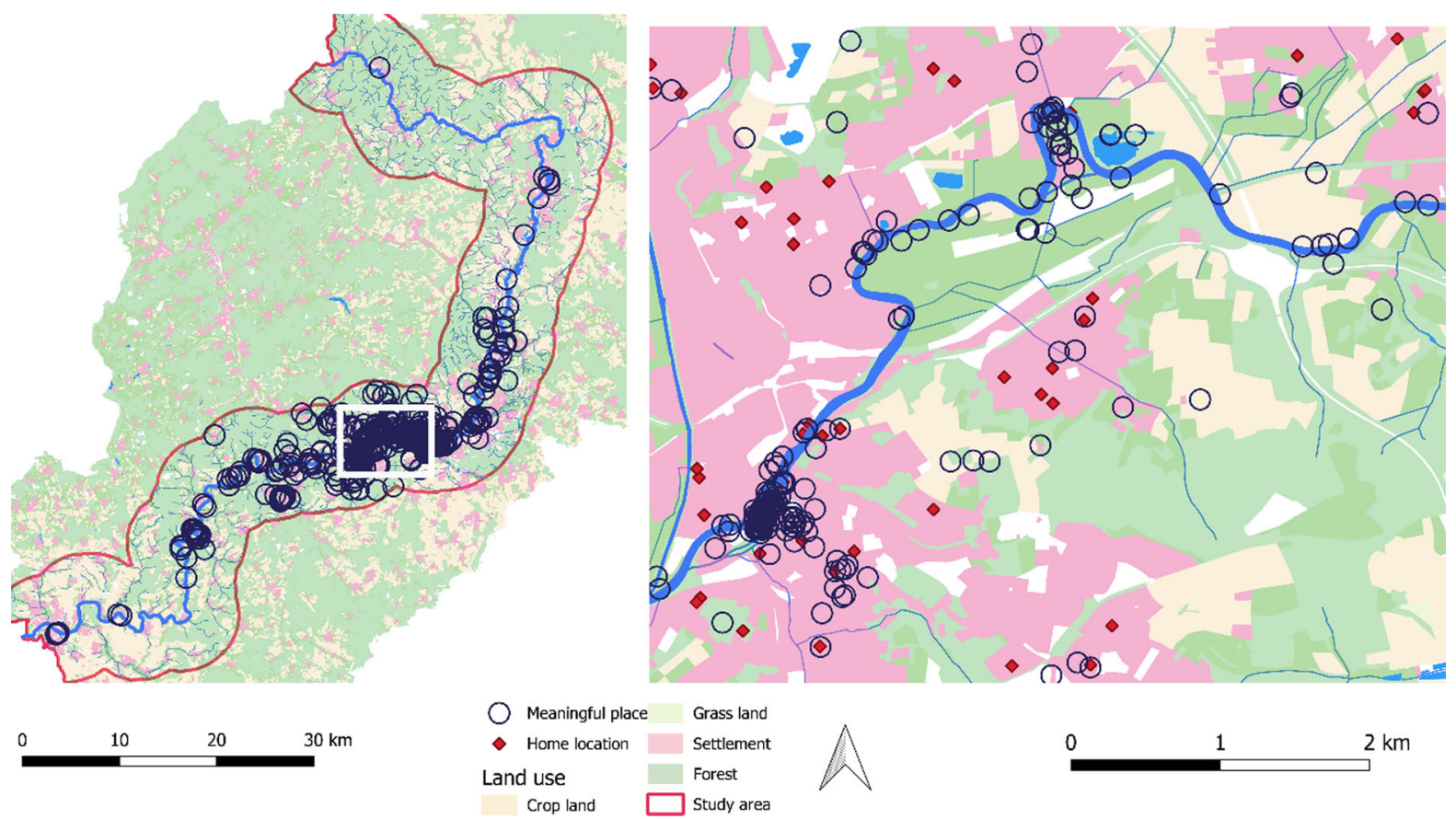

Fig. 3 Spatial distribution of meaningful places within the study area (left) and close up of a central location within the study area displaying distribution of meaningful places and home locations 

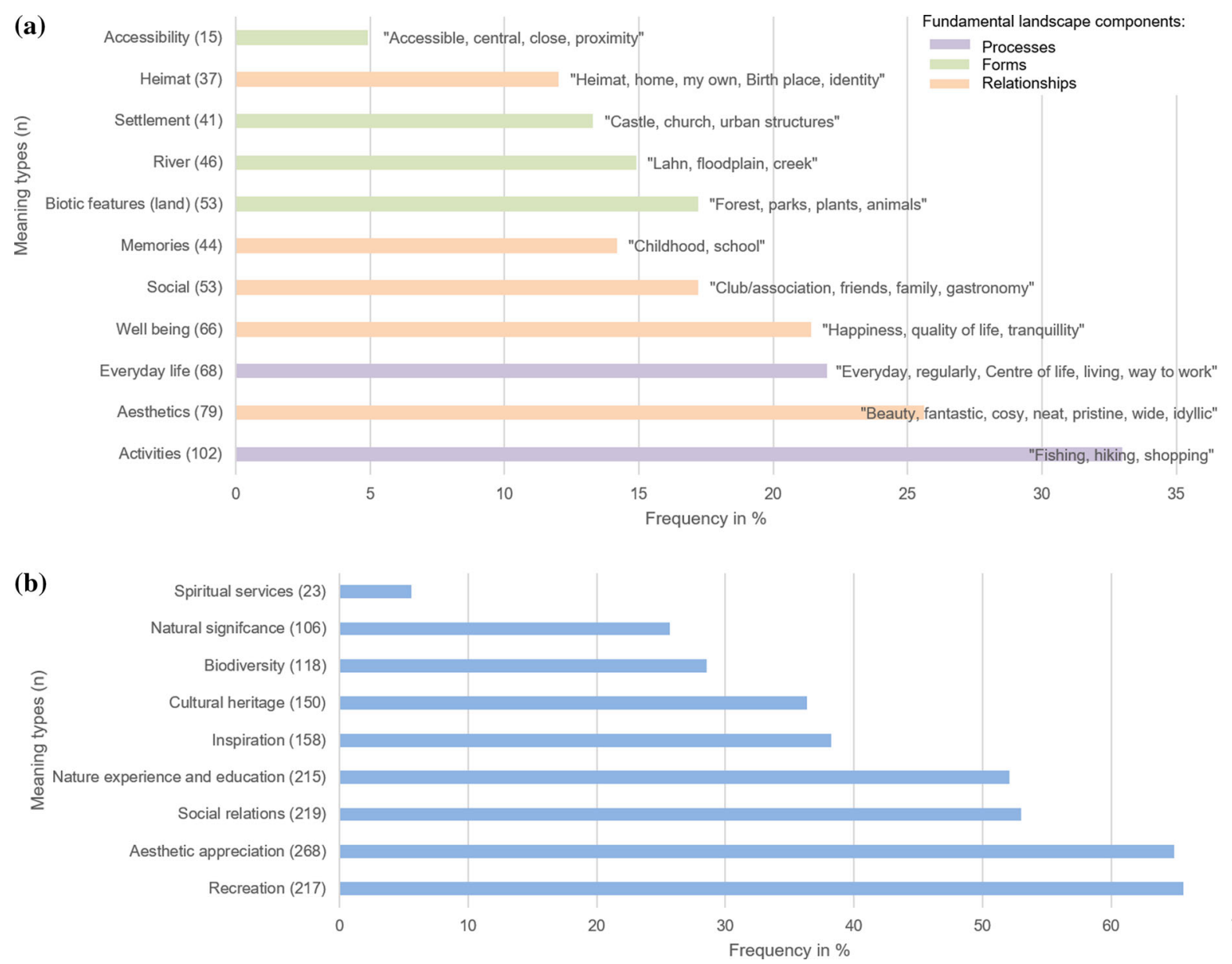

Fig. 4 Frequency of meanings in \%, there are several meaning types at one single place possible, therefore the \% does not add up to $100 \% ;:$ a Place meanings of free listing exercise, $\mathrm{N}=309$.
Coding based on Stephenson (2008); b place meanings based on cultural ecosystem service list $(\mathrm{N}=412)$ (rho $=0.18, \mathrm{p}<0.01$, and rho $=0.19, \mathrm{p}<0.01$, respectively) (Table S.1 in Supplementary Materials).

There were some correlations between meanings revealed through the free listing and the multiple choice (CES) exercise (Table 3). In particular, forms, which mean 'physical, tangible and measurable aspects of landscape or space' (Stephenson 2008, p. 134), such as biotic features and settlement (or human-made structures), show relations to various CESs. Biotic features are significantly positively related to 'Learn about nature', 'Inspiration', 'Plants and animals', and 'Native' as well as to the whole bundle of nature values. They are negatively related to 'friends and family'. Meanings related to human-made structures, such as castles or urban structures, are positively related to values of 'History and culture' and 'Sacred' and negatively related to 'Learn about nature' and 'Inspiration'. Activities, the most frequently listed meaning, are negatively related to 'history and culture' and 'friends and family' and positively related to outdoor recreation. There is no relation between activities and any nature value. Aesthetics are positively related to scenery and negatively related to friends and family. Well-being is positively related to both 'Learn about nature' and 'Inspiration'.

Comparing the free listed meanings with the selected CES shows that forms and processes, such 
Table 3 Correlation between meanings from free listing and CES list and, Spearman's rank correlation coefficient, $\mathrm{n}=300$, $* \mathrm{p}<0.05 ; * \mathrm{p}<0.01$, shaded boxes indicate similar meanings with significant correlation

\begin{tabular}{|c|c|c|c|c|c|c|c|c|c|c|c|}
\hline \multirow{3}{*}{ CES list } & \multicolumn{11}{|c|}{ Free-listing } \\
\hline & \multicolumn{5}{|c|}{ Relationships } & \multicolumn{2}{|c|}{ Practices } & \multicolumn{4}{|c|}{ Forms } \\
\hline & Heimat & $\begin{array}{c}\text { Wellbei } \\
\text { ng }\end{array}$ & $\begin{array}{l}\text { Aestheti } \\
\text { c } \\
\text { apprecia } \\
\text { tion }\end{array}$ & $\begin{array}{c}\text { Social } \\
\text { relations }\end{array}$ & $\begin{array}{c}\text { Memo } \\
\text { ries }\end{array}$ & $\begin{array}{c}\text { Activitie } \\
\mathrm{s}\end{array}$ & $\begin{array}{c}\text { Every } \\
\text { day } \\
\text { life }\end{array}$ & $\begin{array}{l}\text { Settle } \\
\text { ment }\end{array}$ & $\begin{array}{l}\text { Biotic } \\
\text { featur } \\
\text { es } \\
\text { (land) } \\
\end{array}$ & $\begin{array}{l}\text { Access } \\
\text { ibility }\end{array}$ & River \\
\hline $\begin{array}{l}\text { Aesthetic } \\
\text { appreciation }\end{array}$ & -0.014 & 0.033 & $0.142 * *$ & 0.038 & 0.050 & -0.040 & 0.024 & 0.091 & $\begin{array}{r}0.099 \\
*\end{array}$ & $\begin{array}{r}- \\
0.048\end{array}$ & 0.077 \\
\hline $\begin{array}{l}\text { Cultural } \\
\text { heritage }\end{array}$ & $0.131 * *$ & -0.004 & 0.013 & 0.056 & 0.022 & $\begin{array}{r}- \\
0.201 * *\end{array}$ & 0.034 & $\begin{array}{r}0.305 \\
* *\end{array}$ & $\begin{array}{r}- \\
0.004\end{array}$ & $\begin{array}{r}- \\
0.039\end{array}$ & $\begin{array}{r}- \\
0.055\end{array}$ \\
\hline $\begin{array}{l}\text { Nature } \\
\text { experience } \\
\text { and } \\
\text { education }\end{array}$ & 0.030 & $0.142 * *$ & -0.052 & -0.039 & 0.025 & 0.004 & 0.022 & $\begin{array}{r}- \\
0.104 \\
*\end{array}$ & $\begin{array}{r}0.179 \\
* *\end{array}$ & 0.030 & 0.039 \\
\hline $\begin{array}{l}\text { Spiritual } \\
\text { services }\end{array}$ & 0.002 & -0.046 & -0.008 & 0.096 & $\begin{array}{r}- \\
0.014 \\
\end{array}$ & -0.013 & $\begin{array}{r}- \\
0.014 \\
\end{array}$ & $\begin{array}{r}0.202 \\
* * \\
\end{array}$ & 0.001 & $\begin{array}{r}- \\
0.047 \\
\end{array}$ & 0.050 \\
\hline Inspiration & 0.046 & $0.213 * *$ & 0.032 & -0.005 & 0.025 & 0.012 & 0.087 & $\begin{array}{r}- \\
0.095 \\
\end{array}$ & $\begin{array}{r}0.204 \\
* * \\
\end{array}$ & 0.007 & 0.044 \\
\hline Biodiversity & 0.057 & 0.084 & -0.042 & -0.003 & $\begin{array}{r}- \\
0.023 \\
\end{array}$ & 0.008 & $\begin{array}{r}- \\
0.011 \\
\end{array}$ & $\begin{array}{r}- \\
0.049 \\
\end{array}$ & $\begin{array}{r}0.270 \\
* * \\
\end{array}$ & 0.020 & 0.019 \\
\hline $\begin{array}{l}\text { Natural } \\
\text { significance } \\
\text { (native) }\end{array}$ & $0.159 * *$ & 0.069 & 0.003 & 0.056 & 0.017 & 0.007 & $\begin{array}{r}- \\
0.046\end{array}$ & $\begin{array}{r}- \\
0.066\end{array}$ & $\begin{array}{r}0.271 \\
* *\end{array}$ & 0.034 & 0.043 \\
\hline $\begin{array}{l}\text { Social } \\
\text { relations }\end{array}$ & $0.164 * *$ & -0.014 & $0.111^{-}$ & $0.201 * *$ & 0.050 & $0.144^{-} *$ & $\begin{array}{r}0.191 \\
* *\end{array}$ & $\begin{array}{r}- \\
0.045\end{array}$ & $\begin{array}{r}- \\
0.249 \\
* *\end{array}$ & 0.027 & $\begin{array}{r}- \\
0.030\end{array}$ \\
\hline Recreation & 0.018 & 0.083 & 0.031 & 0.063 & $\begin{array}{r}- \\
0.021\end{array}$ & $0.202 * *$ & 0.017 & $\begin{array}{r}- \\
0.034\end{array}$ & 0.002 & $\begin{array}{r}0.140 * \\
*\end{array}$ & $0.121 *$ \\
\hline
\end{tabular}

as natural elements or human activities, are relatively well reflected in the list of CES, which is confirmed by the explored correlations. Activities (meaning) are related to recreation (CES), aesthetics (meaning) to aesthetic appreciation (CES), social (meanings) to social relations (CES), biotic features (meanings) are significantly positively related to all types of 'nature CES', and settlement (meaning) is related to cultural heritage and spiritual services (CES). Everyday life (meaning) shows a significant positive relation to visiting frequency $\left(0.364^{* *}\right)$, which is not a CES but has also been assessed.
However, meanings that describe the relationships (Stephenson 2008) or relational values are not well reflected in the CES list, specifically well-being, memories, and Heimat. Memory-related meanings do not show significant correlations with CES. Wellbeing is significantly positively correlated with nature experiences and education and inspiration, yet these are conceptually different meanings. This correlation is similar for the free listed meaning of Heimat, which shows significant positive relations to natural significance and social relations but cannot be equalized with those items with regard to content. The finalized list of place meaning types is presented in Table 4 . 
Evaluative dimension of sense of place: place attachment

The mean attachment value of the dimensions ranges between 3.37 ( $\mathrm{SD}=0.94$ ) for 'I feel happiest when I' $m$ at this place' and $3.93(\mathrm{SD}=0.89)$ for 'I am very attached to this place' (Table 5).

Relationship meanings, such as Heimat and memories, and practice-related meanings, such as recreation and everyday life, show higher attachment scores than meanings related to forms, such as settlement, river, or nature. The highest attachment scores were found for Heimat $(\mathrm{M}=4.07, \mathrm{SD}=0.58)$, everyday life $(\mathrm{M}=3.95, \quad \mathrm{SD}=0.69), \quad$ spiritual services $(\mathrm{M}=3.95, \mathrm{SD}=0.96)$, and memories $(\mathrm{M}=3.73$, $\mathrm{SD}=0.7)$. Of these, only spiritual services were part of the original CES list. However, overall differences are relatively small and tend to be influenced by the high contrast of frequencies between the meanings. The mean attachment ranges between 4.07 (Heimat) and 3.24 (River).
Relations

\section{Meanings and the physical environment}

Within the study area, the dominant land uses are forest ( $42 \%$ of the total area), followed by cropland (27\%) and grassland (14\%) (Table S. 2 in Supplementary Materials). The distribution of meaning types among these different land uses differs significantly (Table 6). While some meanings are much more present in natural land uses, e.g., natural meanings or recreation, other meanings dominated rather urban land uses, e.g., cultural heritage, social relations, or everyday life. Approximately $21 \%$ of all natural meanings and $9 \%$ of meanings related to cultural heritage are located within grasslands, while this land use type covers $17 \%$ of the study area. Some meaning types are overrepresented in many (different) land uses, e.g., recreation and nature meanings, while others are specific for just one or two land uses, e.g., cultural heritage and Heimat. Almost $60 \%$ of all Heimat-related meanings are within settlements, while the location of recreational meanings is more spread

Table 4 Table representing the final list of place meanings (first column), some additional comments on the sources of the meanings, and place attachment related to each meaning type

\begin{tabular}{|c|c|c|c|c|c|}
\hline \multirow{2}{*}{$\begin{array}{l}\text { Meaning } \\
\text { types }\end{array}$} & \multirow[t]{2}{*}{ Sources } & \multirow{2}{*}{$\begin{array}{l}\mathrm{N} \\
\text { (meanings) }\end{array}$} & \multicolumn{3}{|c|}{ Place attachment } \\
\hline & & & Mean & $\mathrm{SD}$ & $\mathrm{N}$ \\
\hline Recreation & Joined from both sources & 288 & 3.56 & 0.752 & 258 \\
\hline $\begin{array}{l}\text { Aesthetic } \\
\text { appreciation }\end{array}$ & Joined from both sources & 284 & 3.61 & 0.704 & 264 \\
\hline Nature & $\begin{array}{l}\text { Nature experience and education, inspiration, biodiversity, natural significance } \\
\text { from the CES list, and biotic features from the free listing }\end{array}$ & 271 & 3.67 & 0.735 & 246 \\
\hline $\begin{array}{l}\text { Social } \\
\text { relations }\end{array}$ & Joined from both sources & 230 & 3.65 & 0.725 & 210 \\
\hline $\begin{array}{l}\text { Cultural } \\
\text { heritage }\end{array}$ & CES list & 150 & 3.64 & 0.733 & 140 \\
\hline Well-being & Free listing & 66 & 3.52 & 0.676 & 60 \\
\hline Everyday life & Free listing & 65 & 3.95 & 0.694 & 59 \\
\hline River & Free listing & 46 & 3.24 & 0.737 & 41 \\
\hline Memories & Free listing & 44 & 3.73 & 0.704 & 41 \\
\hline Settlement & Free listing & 41 & 3.49 & 0.687 & 40 \\
\hline Heimat & Free listing & 36 & 4.07 & 0.582 & 36 \\
\hline $\begin{array}{l}\text { Spiritual } \\
\text { services }\end{array}$ & CES list & 23 & 3.95 & 0.956 & 21 \\
\hline Accessibility & Free listing & 15 & 3.4 & 0.508 & 13 \\
\hline
\end{tabular}


Table 5 Place attachment reported for each meaningful place, items based on studies by Jorgensen and Stedman (2006), Raymond et al. (2010) and Willams and Vaske (2003); measured on a five-point Likert scale

\begin{tabular}{|c|c|c|c|}
\hline Survey items & $\mathrm{N}$ & Mean & SD \\
\hline I am very attached to this place & 405 & 3.93 & 0.890 \\
\hline This place means a lot to me & 407 & 3.91 & 0.874 \\
\hline I identify strongly with this place & 406 & 3.70 & 0.948 \\
\hline I feel this place is part of me & 401 & 3.47 & 1.053 \\
\hline No other place can compare to this one & 400 & 3.43 & 1.021 \\
\hline I wouldn't substitute any other place for doing the types of things I do here & 405 & 3.25 & 0.996 \\
\hline This place is the best for what I like to do & 407 & 3.53 & 0.936 \\
\hline I get more satisfaction out of being here than at any other place & 404 & 3.54 & 0.930 \\
\hline I feel happiest when I'm at this place & 406 & 3.37 & 0.943 \\
\hline Mean place attachment & 376 & 3.5612 & \\
\hline
\end{tabular}

between settlements (26\%), urban green areas (20\%), rivers and lakes $(18 \%)$, or grasslands $(17 \%)$.

Place attachment ranges from $\mathrm{M}=3.49$ to $\mathrm{M}=3.73$ between the different land use types (Table 7). Similar to the place meanings, the number of places $(\mathrm{N})$ may have a high influence. Meaningful places located within settlement yielded higher place attachment $(\mathrm{M}=3.7, \mathrm{SD}=0.826)$ than places within cropland or grassland (both $\mathrm{M}=3.51, \mathrm{SD}=0.568$ and 0.76 , respectively). However, differences are not significant $(\mathrm{F}=1.573, \mathrm{p}=0.154)$.

For 425 meaningful places, the distance to the respondents' homes could be calculated and ranged between $0 \mathrm{~m}$ and $41 \mathrm{~km}$ with a mean distance of $5.3 \mathrm{~km}$ and a median distance of $2.9 \mathrm{~km}$. The distance to the river ranges between $8 \mathrm{~m}$ and $1.9 \mathrm{~km}$, $\mathrm{M}=457 \mathrm{~m}$, median $=384 \mathrm{~m}$. The share of protected area within a $500 \mathrm{~m}$ distance around meaningful places ranges between 0 and $100 \%$, with a mean value of $11 \%$ for $\mathrm{FFH}$ protected areas and $42 \%$ for landscape protected areas.

Meaningful places related to people's everyday life and Heimat were more frequent close to their homes (rho $=-0.241, \mathrm{p}<0.01$, and rho $=-0.15$, $\mathrm{p}<0.01$, respectively, Table 8 ). In contrast, recreation and river meanings were more frequent further away from home (rho $=0.116, \mathrm{p}<0.05$, and rho $=$ $0.159, \mathrm{p}<0.01$, respectively). Place attachment is highest close to people's homes. Meanings related to settlements are more frequent in close proximity to the river (rho $=-0.107, \mathrm{p}<0.05$ ). Meaningful places related to memories and river meanings showed more landscape protected areas in their immediate surroundings (rho $=0.109, \mathrm{p}<0.05$, and rho $=0.135$, $\mathrm{p}<0.01$, respectively) than meanings related to social relations, Heimat, cultural heritage, and spiritual values (rho $=-0.15, \mathrm{p}<0.01$, rho $=-0.133$, $\mathrm{p}<0.01$, rho $=-0.164, \mathrm{p}<0.01$, and rho $=-$ $0.13, \mathrm{p}<0.01$, respectively). Higher protection status areas (FFH) are more abundant around meaningful places related to nature (rho $=0.095, \mathrm{p}<0.05$ ) and far less around places related to social relations and settlement (rho $=-0.126, \mathrm{p}<0.05$, and rho $=-$ $0.118, \mathrm{p}<0.01$, respectively).

\section{Meanings and socioeconomic settings}

Respondents reported medium-high environmental citizenship (3.3 on a 5-point scale, $\mathrm{SD}=0.75$, $\mathrm{n}=148$ ). Similarly, local knowledge was perceived as medium high $(3.4, \mathrm{SD}=0.69, \mathrm{n}=177)$. The highest values for local knowledge were reported on local knowledge in general (3.7, $\mathrm{SD}=0.73, \mathrm{n}=190)$, whereas local knowledge on social topics, such as the need for social housing, scored lowest $(3.1, \mathrm{SD}=$ 0.94, $\mathrm{n}=192$ ). Local knowledge on environmental topics, such as high biodiversity areas or pollution risks, was rated $3.2(\mathrm{SD}=0.96, \mathrm{n}=192)$.

Environmental citizenship did not show any significant relations with sociodemographic variables (gender, age, education, income). Mean local knowledge and education are significantly positively related (rho $=0.212, \quad \mathrm{p}<0.01) ; \quad$ specifically, education relates positively to local knowledge on economic 
Table 6 Frequency distribution of meaning types amongst different land uses

\begin{tabular}{|c|c|c|c|c|c|c|c|c|c|c|c|c|c|c|}
\hline & 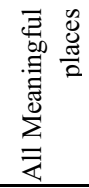 & 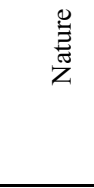 & 㔷 & 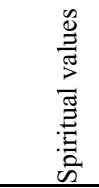 & 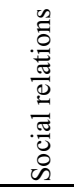 & 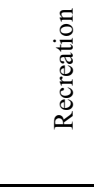 & 营 & $\begin{array}{l}.00 \\
.0 \\
0 \\
\frac{0}{1} \\
0 \\
3\end{array}$ & 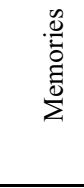 & 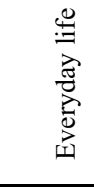 & 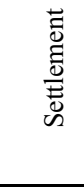 & 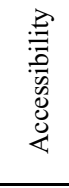 & $\stackrel{\overrightarrow{0}}{a}$ & 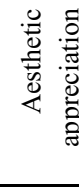 \\
\hline \multicolumn{15}{|l|}{ Cropland } \\
\hline N MP & \multirow{3}{*}{$\begin{array}{r}32 \\
5.7\end{array}$} & 18 & 5 & 0 & 8 & 17 & 2 & 2 & 1 & 1 & 1 & 2 & 2 & 21 \\
\hline$\%$ & & 6.6 & 3.3 & 0.0 & 3.5 & 5.9 & 5.6 & 3.0 & 2.3 & 1.5 & 2.4 & 13.3 & 4.3 & \multirow[t]{2}{*}{7.2} \\
\hline $\mathrm{R}$ & & 1.1 & -1.0 & -1.1 & $\begin{array}{r}- \\
1.1 \\
\end{array}$ & 0.6 & 0.0 & -0.9 & -1.0 & -1.4 & -0.9 & 1.2 & $\begin{array}{r}- \\
0.4\end{array}$ & \\
\hline \multicolumn{15}{|l|}{ Forest } \\
\hline N MP & 58 & 29 & 16 & 3 & 14 & 28 & 0 & 10 & 1 & 2 & 2 & 0 & 4 & 25 \\
\hline$\%$ & 10.4 & 10.7 & 10.7 & 11.1 & 6.1 & 9.7 & 0.0 & 15.2 & 2.3 & 3.1 & 4.9 & 0.0 & 8.7 & \multirow[t]{2}{*}{8.6} \\
\hline $\mathrm{R}$ & & 0.9 & -0.7 & 0.7 & $\begin{array}{r}- \\
1.5 \\
\end{array}$ & 0.4 & -1.9 & 1.2 & -1.7 & -1.8 & -1.1 & $\begin{array}{r}- \\
1.2 \\
\end{array}$ & $\begin{array}{r}- \\
0.4\end{array}$ & \\
\hline \multicolumn{15}{|l|}{ Grassland } \\
\hline N MP & 96 & 56 & 14 & 1 & 25 & 48 & 4 & 14 & 10 & 7 & 3 & 3 & 13 & 48 \\
\hline$\%$ & 17.1 & 20.7 & 9.3 & 3.7 & 10.9 & 16.7 & 11.1 & 21.2 & 22.7 & 10.8 & 7.3 & 20.0 & 28.3 & \multirow{2}{*}{$\begin{array}{r}16.6 \\
- \\
0.2 \\
\end{array}$} \\
\hline $\mathrm{R}$ & & 1.3 & -2.4 & -1.5 & $\begin{array}{r}- \\
2.4 \\
\end{array}$ & -0.3 & -0.9 & 0.8 & 0.9 & -1.2 & -1.5 & 0.3 & 1.8 & \\
\hline \multicolumn{15}{|c|}{$\begin{array}{c}\text { Industrial and } \\
\text { traffic area }\end{array}$} \\
\hline N MP & \multirow{3}{*}{$\begin{array}{r}15 \\
2.7\end{array}$} & 7 & 1 & 4 & 7 & 10 & 1 & 2 & 0 & 3 & 0 & 1 & 3 & 7 \\
\hline$\%$ & & 2.6 & 0.7 & 14.8 & 3.0 & 3.5 & 2.8 & 3.0 & 0.0 & 4.6 & 0.0 & 6.7 & 6.5 & 2.4 \\
\hline $\mathrm{R}$ & & -0.1 & -1.5 & -0.8 & 0.3 & 0.8 & 0.0 & 0.2 & -1.1 & 1.0 & -1.0 & 0.9 & 1.6 & $0 . \overline{2}$ \\
\hline River and la & & & & & & & & & & & & & & \\
\hline N MP & 89 & 43 & 24 & 2 & 37 & 52 & 6 & 10 & 11 & 12 & 9 & 3 & 11 & 48 \\
\hline$\%$ & 15.9 & 15.9 & 16.0 & 7.4 & 16.1 & 18.1 & 16.7 & 15.2 & 25.0 & 18.5 & 22.0 & 20.0 & 23.9 & 16.6 \\
\hline $\mathrm{R}$ & & -0.4 & -0.2 & -0.8 & $\begin{array}{r}- \\
0.2 \\
\end{array}$ & 0.5 & 0.1 & -0.2 & 1,5 & 0.5 & 1.0 & 0.4 & 1.4 & 0.1 \\
\hline Settlement & & & & & & & & & & & & & & \\
\hline N MP & 181 & 73 & 73 & 16 & 89 & 75 & 21 & 14 & 13 & 34 & 21 & 4 & 8 & 93 \\
\hline$\%$ & 32.3 & 26.9 & 48.7 & 59.3 & 38.7 & 26.0 & 58.3 & 21.2 & 29.5 & 52.3 & 51.2 & 26.7 & 17.4 & 32.1 \\
\hline $\mathrm{R}$ & & -1.5 & 3.6 & 3.2 & 1.8 & -1.8 & 2.7 & -1.6 & -0.3 & 2.8 & 2.1 & $\begin{array}{r}- \\
0.4\end{array}$ & $\begin{array}{r}- \\
1.8\end{array}$ & 0.2 \\
\hline Urban gree & & & & & & & & & & & & & & \\
\hline N MP & 89 & 45 & 17 & 1 & 50 & 58 & 2 & 14 & 8 & 6 & 5 & 2 & 5 & 48 \\
\hline$\%$ & 15.9 & 16.6 & 11.3 & 3.7 & 21.7 & 20.1 & 5.6 & 21.2 & 18.2 & 9.2 & 12.2 & 13.3 & 10.9 & 16.6 \\
\hline $\mathrm{R}$ & & -0.2 & -1.7 & -1.5 & 1.7 & 1.3 & -1.6 & 1.1 & 0.4 & -1.3 & -0.6 & $\begin{array}{r}- \\
0.2 \\
\end{array}$ & $\begin{array}{r}- \\
0.9 \\
\end{array}$ & 0.0 \\
\hline Total & & & & & & & & & & & & & & \\
\hline $\mathrm{N}$ & 560 & 271 & 150 & 27 & 230 & 288 & 36 & 66 & 44 & 65 & 41 & 15 & 46 & 290 \\
\hline$\%$ & 100 & 100 & 100 & 100 & 100 & 100 & 100 & 100 & 100 & 100 & 100 & 100 & 100 & 100 \\
\hline $\begin{array}{c}\text { Chi-Square } \\
\text { test }\end{array}$ & & & & & & & & & & & & & & \\
\hline Pearson & & 17.815 & 39.557 & 18.684 & 35.1 & 21.773 & 15.46 & 7.576 & 8.914 & 20.226 & 12.08 & 4.5 & 13.0 & 0.6 \\
\hline $\mathrm{p}$ value & & 0.007 & $\mathbf{0}$ & 0.005 & 0.0 & 0.001 & 0.017 & 0.271 & 0.178 & 0.003 & 0.06 & 0.6 & 0.0 & 1.0 \\
\hline
\end{tabular}

Colored cells indicate significantly more (green) or less (red) frequency of a certain meaning type within this land use type, explanation of the second column: N MP(Meaning type within land use), \% (within meaning type), R (Residual of meaning type) 
Table 7 Relation between place attachment and land use types, ANOVA: $\mathrm{F}=1.573, \mathrm{p}=.154$

\begin{tabular}{llll}
\hline Land use type & \multicolumn{3}{l}{ Place attachment } \\
\cline { 2 - 4 } & $\mathrm{M}$ & $\mathrm{N}$ & $\mathrm{SD}$ \\
\hline Cropland & 3.51 & 19 & 0.568 \\
Forest & 3.62 & 36 & 0.824 \\
Grassland & 3.51 & 64 & 0.760 \\
Industrial and traffic area & 3.73 & 9 & 0.701 \\
River and lake & 3.49 & 64 & 0.653 \\
Settlement & 3.70 & 119 & 0.826 \\
Urban Green & 3.39 & 65 & 0.576 \\
Study area & 3.56 & 376 & 0.737 \\
\hline
\end{tabular}

topics and in general. Income relates positively to selfperceived general local knowledge. Age and gender do not relate to either environmental citizenship or local knowledge. Environmental citizenship is significantly positively related to mean local knowledge and more strongly to local knowledge on environmental topics (Table S.3 in Supplementary Materials).

Neither environmental citizenship nor local knowledge are significantly related to the intensity of place attachment. Furthermore, there are few significant relations between these background variables and types of meanings (Table 9). Environmental citizenship shows a significant positive correlation with nature-related meanings (rho $=0.17, \mathrm{p}<0.01$ ) and cultural heritage $(\mathrm{rho}=0.118, \mathrm{p}<0.05)$. Local knowledge is significantly positively related to spiritual values (rho $=0.127, \mathrm{p}<0.05$ ). Sum of meaning is significantly positively related to local environmental knowledge.

\section{Discussion and conclusions}

This study showed that assessing specific types of place meaning is important to understand the relationship between sense of place (SOP) and biophysical and socioeconomic variables. Additionally, combining both assessment approaches for place meanings showed that CESs are reflected in many different freely listed meanings but omit relationship aspects, such as Heimat or memories. We will discuss these aspects in more detail, while highlighting the synergies between both SOP theory and ecosystem services concept. While the CES concept offers methodological expertise, especially in spatial quantitative assessment, which is lacking in SOP research, the theory of SOP provides an understanding of human-environment relationships. Following, these three points will be discussed in depth.

\section{Meaningful place characteristics}

The most frequent place meanings were recreation, aesthetic appreciation, nature, and social relations, which is in line with findings assessments of cultural ecosystem services in Germany (Plieninger et al. 2013). In relation to place attachment, relationshiprelated meanings, such as Heimat and memories, and practice-related meanings, such as recreation and everyday life, show higher attachment scores than meanings related to forms, such as settlement, river, or nature. In this study, $94 \%$ of places with indicated meanings were valued for more than one meaning. This value is in line with findings on the multiple correlations between cultural ecosystem services (Plieninger et al. 2013) and the idea of the interlinked, holistic nature of cultural ecosystem services (Bieling and Plieninger 2013). However, while Plieninger et al. (2013) found the most and strongest positive significant correlation values for social relations with other CESs, in our study on meanings, social relations showed only negative correlations with two other meaning types (biodiversity, natural significance). This finding could be explained with a different study setting than the present study, where respondents could select various place meanings (CES list and free listing) for the same located meaningful place.

Our study showed that place meanings were significantly related to land use types, but place attachments were not. Settlements, grasslands, rivers, and urban green areas are the most popular land use types to locate meaningful places, but the distribution depends on the type of meaning. While other studies on the relation between the physical environment and SOP do not specify the encountered meanings (Kim and Kaplan 2004; Arnberger and Eder 2012), this study gives a more nuanced picture. It shows that green spaces, such as cropland, forest, or grassland, are indeed significantly positively related to natural meanings but show negative relations to some other meanings, such as cultural heritage or social relations. In contrast, urban land uses show an 
Table 8 Correlation between place meanings and attachment and different physical variables, Spearman's rank correlation coefficient, $\mathrm{n}=300, * \mathrm{p}<0.05 ; * \mathrm{p}<0.01$, significant correlations area highlighted in bold

\begin{tabular}{|c|c|c|c|c|}
\hline Meaning types & Distance to home & Distance to river & Share landscape protection & Share FFH protection \\
\hline \multicolumn{5}{|l|}{ Nature } \\
\hline rho & -0.046 & 0.046 & 0.044 & $0.095^{*}$ \\
\hline $\mathrm{N}$ & 425 & 560 & 560 & 560 \\
\hline \multicolumn{5}{|l|}{ Social relations } \\
\hline rho & -0.078 & -0.091 & $-0.150^{* *}$ & $-0.126^{*}$ \\
\hline $\mathrm{N}$ & 333 & 412 & 412 & 412 \\
\hline \multicolumn{5}{|l|}{ Recreation } \\
\hline rho & $0.116^{*}$ & 0.032 & 0.064 & 0.032 \\
\hline $\mathrm{N}$ & 333 & 412 & 412 & 412 \\
\hline \multicolumn{5}{|c|}{ Aesthetic appreciation } \\
\hline rho & 0.000 & -0.028 & 0.053 & -0.002 \\
\hline $\mathrm{N}$ & 333 & 412 & 412 & 412 \\
\hline \multicolumn{5}{|l|}{ Heimat } \\
\hline rho & $-0.150^{* *}$ & 0.000 & $-\mathbf{0 . 1 3 3}^{* *}$ & -0.050 \\
\hline $\mathrm{N}$ & 425 & 560 & 560 & 560 \\
\hline \multicolumn{5}{|l|}{ Everyday life } \\
\hline rho & $-0.241^{* *}$ & -0.024 & -0.035 & 0.002 \\
\hline $\mathrm{N}$ & 425 & 560 & 560 & 560 \\
\hline \multicolumn{5}{|l|}{ Accessibility } \\
\hline rho & -0.059 & -0.031 & 0.051 & -0.036 \\
\hline $\mathrm{N}$ & 425 & 560 & 560 & 560 \\
\hline \multicolumn{5}{|l|}{ Memories } \\
\hline rho & -0.049 & 0.011 & $0.109^{*}$ & 0.047 \\
\hline $\mathrm{N}$ & 425 & 560 & 560 & 560 \\
\hline \multicolumn{5}{|l|}{ Settlement } \\
\hline rho & 0.078 & $-0.107^{*}$ & -0.053 & $-0.118^{* *}$ \\
\hline $\mathrm{N}$ & 425 & 560 & 560 & 560 \\
\hline \multicolumn{5}{|l|}{ Well-being } \\
\hline rho & 0.037 & 0.026 & 0.025 & 0.052 \\
\hline $\mathrm{N}$ & 425 & 560 & 560 & 560 \\
\hline \multicolumn{5}{|l|}{ River and water } \\
\hline rho & $0.159^{* * *}$ & 0.008 & $0.135^{* *}$ & 0.037 \\
\hline $\mathrm{N}$ & 425 & 560 & 560 & 560 \\
\hline \multicolumn{5}{|l|}{ Cultural heritage } \\
\hline rho & 0.095 & -0.079 & $-0.164^{* *}$ & -0.087 \\
\hline $\mathrm{N}$ & 333 & 412 & 412 & 412 \\
\hline \multicolumn{5}{|l|}{ Spiritual values } \\
\hline rho & -0.017 & -0.082 & $-0.130^{* *}$ & -0.001 \\
\hline $\mathrm{N}$ & 333 & 412 & 412 & 412 \\
\hline \multicolumn{5}{|l|}{ Place attachment } \\
\hline rho & $-0.382^{* *}$ & -0.057 & -0.060 & -0.025 \\
\hline $\mathrm{N}$ & 303 & 376 & 376 & 376 \\
\hline
\end{tabular}


Table 9 Correlation between place attachment, meaning types and psychological attributes, *p $<0.05$;**p $<0.01$, significant correlations area highlighted in bold

\begin{tabular}{|c|c|c|c|c|c|c|c|c|c|c|c|c|}
\hline & \multicolumn{2}{|c|}{$\begin{array}{l}\text { Environmental } \\
\text { citizenship }\end{array}$} & \multicolumn{2}{|c|}{$\begin{array}{l}\text { Social local } \\
\text { knowledge }\end{array}$} & \multicolumn{2}{|c|}{$\begin{array}{l}\text { Environmental } \\
\text { local knowledge }\end{array}$} & \multicolumn{2}{|c|}{$\begin{array}{l}\text { Economic local } \\
\text { knowledge }\end{array}$} & \multicolumn{2}{|c|}{$\begin{array}{l}\text { General local } \\
\text { knowledge }\end{array}$} & \multicolumn{2}{|c|}{$\begin{array}{l}\text { Mean local } \\
\text { knowledge }\end{array}$} \\
\hline & rho & $\mathrm{N}$ & rho & $\mathrm{N}$ & rho & $\mathrm{N}$ & rho & $\mathrm{N}$ & rho & $\mathrm{N}$ & rho & $\mathrm{N}$ \\
\hline Place attachment & 0.041 & 264 & 0.041 & 376 & 0.011 & 376 & 0.094 & 376 & 0.044 & 376 & 0.105 & 341 \\
\hline \multicolumn{13}{|l|}{ Meaning types } \\
\hline Nature & $0.170^{* *}$ & 289 & -0.005 & 412 & -0.020 & 412 & -0.066 & 412 & -0.012 & 412 & 0.042 & 373 \\
\hline Everyday life & -0.076 & 381 & 0.069 & 560 & -0.008 & 560 & 0.015 & 560 & 0.000 & 560 & 0.000 & 480 \\
\hline Heimat & 0.014 & 381 & 0.032 & 560 & 0.063 & 560 & 0.033 & 560 & 0.027 & 560 & 0.043 & 480 \\
\hline Aesthetic appreciation & 0.008 & 289 & -0.045 & 412 & 0.039 & 412 & -0.007 & 412 & 0.021 & 412 & -0.042 & 373 \\
\hline Social relations & 0.048 & 289 & 0.028 & 412 & 0.071 & 412 & 0.054 & 412 & 0.066 & 412 & 0.060 & 373 \\
\hline Recreation & -0.042 & 289 & -0.005 & 412 & 0.017 & 412 & -0.007 & 412 & -0.002 & 412 & -0.044 & 373 \\
\hline River and lakes & -0.078 & 381 & -0.014 & 560 & 0.043 & 560 & 0.008 & 560 & 0.012 & 560 & -0.038 & 480 \\
\hline Well-being & 0.050 & 381 & 0.023 & 560 & 0.039 & 560 & -0.007 & 560 & -0.016 & 560 & -0.017 & 480 \\
\hline Settlement & -0.057 & 381 & 0.018 & 560 & 0.060 & 560 & 0.056 & 560 & 0.021 & 560 & -0.030 & 480 \\
\hline Memories & -0.032 & 381 & 0.005 & 560 & 0.032 & 560 & -0.056 & 560 & -0.004 & 560 & -0.049 & 480 \\
\hline Accessibility & -0.098 & 381 & 0.049 & 560 & 0.038 & 560 & 0.032 & 560 & -0.022 & 560 & -0.040 & 480 \\
\hline Cultural heritage & $0.118^{*}$ & 289 & 0.021 & 412 & 0.079 & 412 & 0.035 & 412 & 0.042 & 412 & 0.091 & 373 \\
\hline Spiritual values & 0.081 & 289 & 0.042 & 412 & $0.107^{*}$ & 412 & $0.097^{*}$ & 412 & 0.051 & 412 & $0.127^{*}$ & 373 \\
\hline Sum of meanings & 0.052 & 289 & 0.033 & 412 & $0.097^{*}$ & 412 & 0.027 & 412 & 0.050 & 412 & 0.074 & 373 \\
\hline
\end{tabular}

overrepresentation of meanings related to cultural heritage, spiritual values, and social relations. This association highlights that knowledge of the type of meaning is crucial for understanding the relationship between SOP and the physical environment. This may also explain why some studies, omitting these nuances, did not find any relation between, for example, neighborhood greenness and SOP (McCunn and Gifford 2014). Within this study, respondents reported a stronger attachment to meaningful places located within settlements than places within cropland or grassland, yet there was no significant relation to be found. This relation supports findings indicating that place meanings act as a mediator between place attachment and the physical environment (Stedman 2003). However, place attachment showed a significant relation to the distance from home, being strongest at close distances. This relation seems very linear, in contrast to studies on the spatial scale of place attachment, which show a U-shaped curve, demonstrating stronger attachment at the closest place (e.g., apartment), relatively lower attachment at a medium scale and again higher attachment at a smaller scale (Hidalgo and Hernandez 2001; Lewicka 2010;
Devine-Wright and Batel 2017). This scale-dependent attachment, however, can be linked to the assessment method. In our study, the farthest distance was $41 \mathrm{~km}$, which differs largely from the studies above, which used concepts of house/apartment, neighborhood, city, country, and world.

Similarly, personal attributes are not significantly related to place attachment intensity but to the sum of meanings and some meaning types, such as nature and cultural heritage. Respondents with higher environmental local knowledge associated more meanings with their located meaningful places.

While we could not confirm that environmental attitudes are positively related to the perception of meanings (Arias-Arévalo et al. 2017), environmental citizenship showed a significant positive correlation with nature-related meanings. In contrast to other studies (Lin and Lockwood 2014), there was no association between local knowledge or environmental citizenship and place attachment. Furthermore, we could not confirm any association with sociodemographic variables, as has been found in other studies in relation to the perception of the ecosystem's capacity (Martín-López et al. 2012; Fagerholm et al. 2019). 
Based on these findings, we would like to expand Raymond et al.'s (2017) argument that SOP is a process of both attributes of the place and the individual. These individual attributes are complex character traits and preferences, such as local knowledge or environmental citizenship, rather than simple characteristics, such as gender or age.

Synergies between CES concept and sense of place theory

The concept of CES provided a broad range of meanings - especially on practices and forms, such as nature or recreation-but did not account for meanings related to relationships, such as Heimat or memories. The spatially precise assessment of SOP is challenging, and meanings are difficult to assess within surveys. Although the term seems straightforward and understandable relating to people's everyday life, answering can still pose a problem. Reasons can be twofold. First, open questions require more effort to answer than only ticking multiple choice boxes. Second, the place meaning may not be very obvious, and its articulation may require some reflection. Kenter et al. (2011) highlight that deliberative processes, i.e., communication among actors, are more suitable for revealing transcendental or deeper held values than instrumental approaches (Raymond et al. 2014). Here, the provided list of meanings within the survey, based on CES, proved to cover a broad range of meanings that were mentioned in the free listing exercise by participants. However, relationship meanings, as understood by Stephenson (2008), were not covered, such as Heimat, which has been listed frequently by participants also showing a relatively high place attachment score. This observation is in line with findings from Fagerholm et al. (2016), who asked respondents about the contribution of the local landscape to subjective well-being and found that values or meanings such as "tranquility/relaxation, place attachment, quality of life/living well, and comfort/everything is close" were not reflected in the provided ecosystem services framework. According to the layers of place meanings by Williams (2014), we could conclude that CESs are able to cover instrumental meanings, such as nature-related meanings, and sociocultural meanings, such as social relations. Instrumental meanings can be seen as more utilitarian and very tight to place characteristics, whereas sociocultural meanings are constructed within the social or geographic context. However, "deep meanings" (Williams 2014), which are more individual and subjective, such as Heimat or memories, have been ignored. These meanings and others that have been omitted should be integrated in future studies assessing the SOP and relational values linked to ecosystem services, as we could show that the type of meaning matters substantially in understanding the character of the meaningful place.

While SOP is often considered one service of the CES category (MEA 2005), this study has shown that measuring SOP as a CES using just one single item, i.e., 'sense of place' may not capture the full complexity of this theory about human-nature relationships. Some spatial assessments of (cultural) ecosystem services include SOP. For example, Plieninger et al. (2013) measured 'Sites that foster a sense of authentic human attachment, in German language commonly epitomized as Heimat ("home")' as a CES. In other studies, SOP was joined with other concepts (e.g., local identity, personal fulfilment) and translated into ' $\mathrm{I}$ am inspired by feelings, new thoughts, religious or spiritual meanings, etc.'. Poe et al. (2016) demonstrated that materialized or tangible values such as shellfish harvesting present not only provisioning activities as understood in the ES approach but also cultural practices that are strongly connected to SOP. This connection highlights that SOP cannot be simply regarded as one kind of CES. In line with this, the present study has demonstrated the importance of different types of meanings for understanding people-place relationships. These meanings remain underexplored in studies that integrate 'sense of place' as a single item measure. This shortcoming may also explain why SOP is one of the most neglected CESs (Hausmann et al. 2016).

In contrast to approaches that understand SOP as a CES, this research shows that SOP can be understood as an overarching frame for elucidating humanenvironment relationships, in which the CES represents - at least part of - the meanings. Therefore, SOP may serve as the theoretical backbone and overarching concept to understand and assess emotional connections to river landscapes. Consequently, within this study, CES were understood as place meanings, which can represent descriptive adjectives (e.g., aesthetically beautiful), place characteristics (e.g., variety of plants and animals), or symbolic interpretations (e.g., 
spiritual values), following the typology of Masterson et al. (2017). However, we agree with Ryfield et al. (2019) in that a stronger connection of both the ecosystem services concept and the theory of SOP yields great potential. A SOP theory can further contribute to the scientific discourse on relational values linked to ecosystem services. Further, it can provide theoretical depth and methodological opportunities for the concept of relational values linked to the concept of ES (Ross et al. 2018). For relational values, it is highly important to include "nonelite" and "non-Western" knowledge" (Saxena et al. 2018), which may inhibit quantitative studies of relational values (Schulz and Martin-Ortega 2018). However, Masterson et al. (2017) argue that SOP is perceived subjectively but varies systematically, allowing for quantitative assessments. In line with this, Schulz and Martin-Ortega (2018) argue for a more quantitative assessment of relational values to account for different views through the representation of a larger group of people, as has been done in the present study. However, no systematic overview exists thus far regarding the relations between SOP and CES and considering the complexity of both concepts and respective literature. To address this gap, future research should include progressive as well as essentialist perspectives of SOP and place (Di Masso et al. 2019; Lewicka et al. 2019), cultural ecosystem service concepts, and relational values (Arias-Arévalo et al. 2017; Chan et al. 2018).

For planning and management purposes, the synergy of SOP and ecosystem services holds potential. Both seek to contribute to the understanding of motivations or reasons for environmental stewardship (Chapin and Knapp 2015; Schulz and Martin-Ortega 2018). However, SOP theory provides insights into people's environmental behavior and local environmental citizenship (e.g., Krasny et al. 2014; Gottwald and Stedman 2020), which is much more elaborated than the connection between environmental stewardship and ecosystem services. However, this knowledge is very helpful for planners to target their participatory activities. Relational values have been shown to motivate participation, for example, in river landscape management (Mould et al. 2020). However, we have shown in this study that relational meanings were neglected within the list of CESs used. This study provides an additional contribution for the combination of SOP and ecosystem services to close the knowledge gap on the emotional connectedness of people to nature in river landscapes (Verbrugge et al. 2019). Finally, this study calls for a stronger integration of both SOP theory and the ecosystem services concept in future research. Using established lists of CESs and amending them with relational meanings, such as memories or Heimat, can provide a method for spatial and easy quantitative assessment of place meanings to gain a deeper understanding of the emotional connection between people and their environment.

Acknowledgements This research was funded by the German Federal Ministry for Education and Research, Bundesministerium für Bildung und Forschung (BMBF), through a grant for the PlanSmart research group (Funding Code: 01UU1601A), by the Graduate Academy of the University of Hannover for the data assessment (Project Number 60470376), and by the Academy of Finland (Grant Number 321555). Special thanks are offered to the participants of the survey. We thank the anonymous reviewers for the constructive feedback and Thea Kelly for assistance in performing a language check.

Funding Open Access funding enabled and organized by Projekt DEAL.

Open Access This article is licensed under a Creative Commons Attribution 4.0 International License, which permits use, sharing, adaptation, distribution and reproduction in any medium or format, as long as you give appropriate credit to the original author(s) and the source, provide a link to the Creative Commons licence, and indicate if changes were made. The images or other third party material in this article are included in the article's Creative Commons licence, unless indicated otherwise in a credit line to the material. If material is not included in the article's Creative Commons licence and your intended use is not permitted by statutory regulation or exceeds the permitted use, you will need to obtain permission directly from the copyright holder. To view a copy of this licence, visit http://creativecommons.org/licenses/by/4.0/.

\section{References}

Albert C, Schröter B, Haase D, Brillinger M, Henze J, Herrmann S, Gottwald S, Guerrero P, Nicolas C, Matzdorf B (2019) Addressing societal challenges through nature-based solutions: how can landscape planning and governance research contribute? Landsc Urban Plan 182:12-21

Arias-Arévalo P, Martín-López B, Gómez-Baggethun E (2017) Exploring intrinsic, instrumental, and relational values for sustainable management of social-ecological systems. Ecol Soc 22(4) 
Arnberger A, Eder R (2012) The influence of green space on community attachment of urban and suburban residents. Urban For Urban Green 11(1):41-49

Bieling C, Plieninger T (2013) Recording manifestations of cultural ecosystem services in the landscape. Landsc Res 38(5):649-667

BKG (2016) Digital basic landscape model (AAA Modelling) basic-DLM (AAA), pp 1-62

Brown G, Reed P, Raymond CM (2020) Mapping place values: 10 lessons from two decades of public participation GIS empirical research. Appl Geogr

Brown G, Brabyn L (2012) An analysis of the relationships between multiple values and physical landscapes at a regional scale using public participation GIS and landscape character classification. Landsc Urban Plan 107(3):317-331

Brown G, Fagerholm N (2015) Empirical PPGIS/PGIS mapping of ecosystem services: a review and evaluation. Ecosyst Serv 13:119-133

Brown G, Raymond CM (2007) The relationship between place attachment and landscape values: toward mapping place attachment. Appl Geogr 27(2):89-111

Chan KM, Gould RK, Pascual U (2018) Editorial overview: relational values: what are they, and what's the fuss about? Curr Opin Environ Sustain 35:A1-A7

Chan KMA, Satterfield T, Goldstein J (2012) Rethinking ecosystem services to better address and navigate cultural values. Ecol Econ 74:8-18

Chapin FS, Knapp CN (2015) Sense of place: a process for identifying and negotiating potentially contested visions of sustainability. Environ Sci Policy 53(Part A):38-46

Colley K, Craig T (2019) Natural places: Perceptions of wildness and attachment to local greenspace. J Environ Psychol 61:71-78

Cundill G, Bezerra JC, De Vos A, Ntingana N (2017) Beyond benefit sharing: place attachment and the importance of access to protected areas for surrounding communities. Ecosyst Serv 28:140-148

Devine-Wright P, Batel S (2017) My neighbourhood, my country or my planet? The influence of multiple place attachments and climate change concern on social acceptance of energy infrastructure. Glob Environ Chang 47:110-120

Di Masso A, Williams DR, Raymond CM, Buchecker M, Degenhardt B, Devine-Wright P, Hertzog A, Lewicka M, Manzo L, Shahrad A, Stedman R, Verbrugge L, von Wirth $T$ (2019) Between fixities and flows: navigating place attachments in an increasingly mobile world. J Environ Psychol 61:125-133

Díaz S, Pascual U, Stenseke M, Martín-López B, Watson RT, Molnár Z, Hill R, Chan KMA, Baste IA, Brauman KA, Polasky S, Church A, Lonsdale M, Larigauderie A, Leadley PW, van Oudenhoven APE, van der Plaat F, Schröter M, Lavorel S, Aumeeruddy-Thomas Y, Bukvareva E, Davies K, Demissew S, Erpul G, Failler P, Guerra CA, Hewitt CL, Keune H, Lindley S, Shirayama Y (2018) Assessing nature's contributions to people. Science 359(6373):270-272

Dudgeon D, Arthington AH, Gessner MO, Kawabata Z-I, Knowler DJ, Lévêque C, Naiman RJ, Prieur-Richard A-H, Soto D, Stiassny MLJ, Sullivan CA (2006) Freshwater biodiversity: importance, threats, status and conservation challenges. Biol Rev 81(02): 163

Fagerholm N, Oteros-Rozas E, Raymond CM, Torralba M, Moreno G, Plieninger T (2016) Assessing linkages between ecosystem services, land-use and well-being in an agroforestry landscape using public participation GIS. Appl Geogr 74:30-46

Fagerholm N, Torralba M, Moreno G, Girardello M, Herzog F, Aviron S, Burgess P, Crous-Duran J, Ferreiro-Domínguez N, Graves A, Hartel T, Măcicăsan V, Kay S, Pantera A, Varga A, Plieninger T (2019) Cross-site analysis of perceived ecosystem service benefits in multifunctional landscapes. Glob Environ Chang 56:134-147

Garcia-Martin M, Fagerholm N, Bieling C, Gounaridis D, Kizos T, Printsmann A, Müller M, Lieskovský J, Plieninger T (2017) Participatory mapping of landscape values in a PanEuropean perspective. Landsc Ecol 32(11):2133-2150

Gottwald S, Stedman RC (2020) Preserving ones meaningful place or not? Understanding environmental stewardship behaviour in river landscapes. Landsc Urban Plan 198:103778

Hasanzadeh K, Broberg A, Kyttä M (2017) Where is my neighborhood? A dynamic individual-based definition of home ranges and implementation of multiple evaluation criteria. Appl Geogr 84(July):1-10

Hasanzadeh K, Laatikainen T, Kyttä M (2018) A place-based model of local activity spaces: individual place exposure and characteristics. J Geogr Syst 20(3):227-252

Hausmann A, Slotow R, Burns JK, Di Minin E (2016) The ecosystem service of sense of place: benefits for human well-being and biodiversity conservation. Environ Conserv 43(02): 117-127

Hidalgo MC, Hernandez B (2001) Place attachment: conceptual and empirical questions. J Environ Psychol 21(3):273-281

HMUKLV (2015) Bewirtschaftungsplan Hessen 2015-2021

Ingalls M, Stedman R, Society for Human Ecology M, Stedman R (2016) Engaging with human identity in social-ecological systems: a dialectical approach. Human Ecol Rev 1-19

Ives CD, Biggs D, Hardy MJ, Lechner AM, Wolnicki M, Raymond CM (2015) Using social data in strategic environmental assessment to conserve biodiversity. Land Use Policy 47:332-341

Kainzinger S, Arnberger A, Burns RC (2018) An Examination of whitewater boaters' place attachment and specialization in four different river settings. Environ Manage 62(5):832-844

Kenter JO, Hyde T, Christie M, Fazey I (2011) The importance of deliberation in valuing ecosystem services in developing countries-Evidence from the Solomon Islands. Glob Environ Chang 21(2):505-521

Kim J, Kaplan R (2004) Physical and psychological factors in sense of community. Environ Behav 36(3):313-340

Klain SC, Olmsted P, Chan KMA, Satterfield T (2017) Relational values resonate broadly and differently than intrinsic or instrumental values, or the New Ecological Paradigm. PLOS One 12(8): $\mathrm{e} 0183962$

Knaps F, Herrmann S (2018) Analyzing cultural markers to characterize regional identity for rural planning. Rural Landsc Soc Environ Hist 5(1):1

Krasny ME, Crestol SR, Tidball KG, Stedman RC (2014) New York City's oyster gardeners: Memories and meanings as 
motivations for volunteer environmental stewardship. Landsc Urban Plan 132:16-25

Kyttä M, Broberg A, Haybatollahi M, Schmidt-Thomé K (2015) Urban happiness: context-sensitive study of the social sustainability of urban settings. Environ Plann B Plann Des 47:1-24

Lewicka M (2010) What makes neighborhood different from home and city? Effects of place scale on place attachment. J Environ Psychol 30(1):35-51

Lewicka M (2011) Place attachment: how far have we come in the last 40 years? J Environ Psychol 31(3):207-230

Lewicka M, Rowiński K, Iwańczak B, Bałaj B, Kula AM, Oleksy T, Prusik M, Toruńczyk-Ruiz S, Wnuk A (2019) On the essentialism of places: between conservative and progressive meanings. J Environ Psychol 65:101318

Lin C-C, Lockwood M (2013) Assessing sense of place in natural settings: a mixed-method approach. J Environ Plann Manag 0568:1-24

Lin C-CC, Lockwood M (2014) Forms and sources of place attachment: evidence from two protected areas. Geoforum 53:74-81

Manzo LC (2005) For better or worse: Exploring multiple dimensions of place meaning. J Environ Psychol 25(1):67-86

Markle GL (2013) Pro-environmental behavior: does it matter how it's measured? Development and validation of the proenvironmental behavior scale (PEBS). Hum Ecol 41(6):905-914

Martín-López B, Iniesta-Arandia I, García-Llorente M, Palomo I, Casado-Arzuaga I, DelAmo DG, Gómez-Baggethun E, Oteros-Rozas E, Palacios-Agundez I, Willaarts B, González JA, Santos-Martín F, Onaindia M, López-Santiago C, Montes C (2012) Uncovering ecosystem service bundles through social preferences. PLoS One 7(6):e38970

Massey D (1991) A global sense of place. Marxism Today 24-29

Masterson VA, Stedman RC, Enqvist J, Tengö M, Giusti M, Wahl D, Svedin U (2017) The contribution of sense of place to social-ecological systems research: a review and research agenda. Ecol Soc 22(1):art49

McCunn LJ, Gifford R (2014) Interrelations between sense of place, organizational commitment, and green neighborhoods. Cities 41(PA):20-29

MEA (2005) Ecosystems and human well-being. Health synthesis. A report of the millennium ecosystem assessment core

Mould SA, Fryirs KA, Howitt R (2020) The importance of relational values in river management: understanding enablers and barriers for effective participation. Ecol Soc 25(2):1-16

Perchoux C, Chaix B, Cummins S, Kestens Y (2013) Conceptualization and measurement of environmental exposure in epidemiology: accounting for activity space related to daily mobility. Health Place 21:86-93

Plieninger T, Dijks S, Oteros-Rozas E, Bieling C (2013) Assessing, mapping, and quantifying cultural ecosystem services at community level. Land Use Policy 33:118-129

Poe MR, Donatuto J, Satterfield T (2016) "Sense of Place": human wellbeing considerations for ecological restoration in puget sound. Coast Manag 44(5):409-426
Rall E, Bieling C, Zytynska S, Haase D (2017) Exploring citywide patterns of cultural ecosystem service perceptions and use. Ecol Ind 77:80-95

Ratter BMW, Gee K (2012) Heimat - A German concept of regional perception and identity as a basis for coastal management in the Wadden Sea. Ocean Coast Manag 68:127-137

Raymond CM, Brown G, Weber D (2010) The measurement of place attachment: Personal, community, and environmental connections. J Environ Psychol 30(4):422-434

Raymond CM, Kenter JO, Plieninger T, Turner NJ, Alexander KA (2014) Comparing instrumental and deliberative paradigms underpinning the assessment of social values for cultural ecosystem services. Ecol Econ 107:145-156

Raymond CM, Kyttä M, Stedman R (2017) Sense of place, fast and slow: the potential contributions of affordance theory to sense of place. Front Psychol 8

Ross H, Witt K, Jones NA (2018) Stephen Kellert's development and contribution of relational values in social-ecological systems. Curr Opin Environ Sustain 35:46-53

Ryan RL (2011) The social landscape of planning: Integrating social and perceptual research with spatial planning information. Landsc Urban Plan 100(4):361-363

Ryfield F, Cabana D, Brannigan J, Crowe T (2019) Conceptualizing 'sense of place' in cultural ecosystem services: a framework for interdisciplinary research. Ecosyst Serv

Saxena AK, Chatti D, Overstreet K, Dove MR (2018) From moral ecology to diverse ontologies: relational values in human ecological research, past and present. Curr Opin Environm Sustain 35:54-60

Schulz C, Martin-Ortega J (2018) Quantifying relational values - why not? Curr Opin Environ Sustain 35:15-21

Stedman RC (2008) What do we "Mean" by Place Meanings? Implications of place meanings for managers and practitioners. In: Kruger LE, Troy HE, Stiefel MC (eds) Understanding concepts of place in recreation research. Gen. Tech. Rep. PNW-GTR-744. Portland: U.S. Department of Agriculture, Forest Service, Pacific Northwest Research Station, pp 61-82

Stedman RC (2003) Is it really just a social construction?: the contribution of the physical environment to sense of place. Soc Nat Resour 16(8):671-685

Stedman RC (2006) Understanding place attachment among second home owners. Am Behav Sci 50(2):187-205

Stedman RC (2016) Subjectivity and social-ecological systems: a rigidity trap (and sense of place as a way out). Sustain Sci 11(6):891-901

Stephenson J (2008) The cultural values model: an integrated approach to values in landscapes. Landsc Urban Plan 84(2):127-139

Thiele J, von Haaren C, Albert C (2019) Are river landscapes outstanding in providing cultural ecosystem services? An indicator-based exploration in Germany. Ecol Ind 101(June):31-40

Tonge J, Moore SA, Ryan MM, Beckley LE (2013) A photoelicitation approach to exploring the place meanings ascribed by campers to the Ningaloo Coastline, NorthWestern Australia. Aust Geogr 44(2):143-160

Tuan Y (1977) Space and place: the perspective of experience. Minneapolis, MN: University of Minnesota Press 
Verbrugge L, Buchecker M, Garcia X, Gottwald S, Müller S, Præstholm S, Stahl Olafsson A (2019) Integrating sense of place in planning and management of multifunctional river landscapes: experiences from five European case studies. Sustain Sci 14(3):669-680

Vörösmarty CJ, McIntyre PB, Gessner MO, Dudgeon D, Prusevich A, Green P, Glidden S, Bunn SE, Sullivan CA, Liermann CR, Davies PM (2010) Global threats to human water security and river biodiversity. Nature 467(7315):555-561

Wantzen KM, Ballouche A, Longuet I, Bao I, Bocoum H, Cissé L, Chauhan M, Girard P, Gopal B, Kane A, Marchese MR, Nautiyal P, Teixeira P, Zalewski M (2016) River culture: an eco-social approach to mitigate the biological and cultural diversity crisis in riverscapes. Ecohydrol Hydrobiol 16(1):7-18
Wartmann FM, Purves RS (2018) Investigating sense of place as a cultural ecosystem service in different landscapes through the lens of language. Landsc Urban Plan 175:169-183

Williams DR (2014) Making sense of 'place': reflections on pluralism and positionality in place research. Landsc Urban Plan 131:74-82

Williams DR, Vaske JJ (2003) The measurement of place attachment: validity and generalizability of a psychometric approach. For Sci 49(6):830-840

Publisher's Note Springer Nature remains neutral with regard to jurisdictional claims in published maps and institutional affiliations. 